\title{
Análise crítica do discurso: modismo, teoria ou método?
}

\author{
Critical Discourse Analysis: \\ Fad, Theory or Method?
}

Adail Sebastião Rodrigues-Júnior*

Universidade Federal de Ouro Preto

RESUMO: A Análise Crítica do Discurso (ACD) tem sido considerada uma teoria potencial para o entendimento das relações de poder e das ideologias frequentemente presentes no discurso. Vários teóricos concordam que a ACD tem contribuído para a compreensão de inúmeros fenômenos linguísticos que, mormente, retratam hegemonias opacas, uma vez que a linguagem é um instrumento poderoso para a disseminação de conceitos preconcebidos, bem como de ideologias. No entanto, por que a ACD recebeu, nos anos noventa, críticas severas de um conjunto significativo de teóricos? Essas críticas apresentaram uma lista ampla de problemas relacionados aos métodos e abordagens utilizados por analistas críticos do discurso. Dentre essas críticas, os problemas de recepção e representatividade são tidos como os mais frequentes no tratamento dos dados feito pelos pesquisadores. Apesar de tudo isso, a determinação dos analistas críticos do discurso em apresentar uma base metodológica à disciplina teve seus resultados positivos - a ACD é hoje um ramo reconhecido da Linguística Aplicada no exterior, dentro da interface entre as Ciências Sociais e as Humanidades. Publicações recentes, principalmente as de Fairclough e seus colegas, levaram em consideração algumas dessas críticas, ao responderem pontualmente às mesmas. Contudo, no Brasil tem havido um "silêncio" em relação a essa questão, sobretudo porque os pesquisadores parecem desconsiderar tais críticas. Neste artigo, pretendo "quebrar esse silêncio" e discutir algumas dessas críticas e seus impactos na ACD e sua aplicação em pesquisas brasileiras. O objetivo principal deste artigo é perceber se algumas pesquisas em ACD no Brasil têm apresentado os mesmos problemas postos por esses críticos, através da análise de quatro artigos que usam a ACD como teoria orientadora, publicados em um número especial sobre a ACD de um reconhecido periódico brasileiro intitulado D.E.L.T.A. Os resultados indicaram que alguns dos problemas mostrados por esses críticos também aparecem nos artigos analisados, o que indica que os analistas críticos do discurso brasileiros precisam atentar para a maneira como abordam e tratam seus dados.

PALAVRAS-CHAVE: análise crítica do discurso; crítica; recepção; representatividade; pesquisa.

*adail.sebastiao@terra.com.br 


\begin{abstract}
Critical Discourse Analysis (CDA) has been considered a potential theory for the unveiling of power relations and ideologies commonly found in discourse. Many theoreticians agree on the fact that CDA has contributed to the understanding of several linguistic phenomena that usually portray obfuscated hegemonies, since language is a powerful tool for disseminating biased assumptions as well as ideologies. Nonetheless, why did CDA attract severe criticisms from a wide range of scholars in the 1990s? These critics presented a full list of problems concerning the methods and approaches often utilized by critical discourse analysts. Among the criticisms, problems of reception and representativeness are claimed to pervade most of the treatment given by CDA researchers to their data. Despite all this, the keenness of critical discourse analysts to display a methodological ground to the discipline has had its positive results - CDA is now a recognized and well-established branch of Applied Linguistics in the international context, within the interface between the Social Sciences and the Humanities. Recent publication, principally from Fairclough and his colleagues, has taken into considerable account some of the criticisms, by responding to these critics accordingly. In Brazil, however, there has been a "deafening silence" about this issue, especially because researchers seem to disregard these criticisms. In this paper, I intend to "break this silence" and bring into discussion some of these criticisms and their impact on CDA and the application of its theory in Brazilian research. The main aim of the paper is to see whether some research on CDA in Brazil has presented the same problems posed by these critics, by analyzing four articles that use CDA as an orienting theory, published in a special issue on CDA from a well-known Brazilian journal entitled D.E.L.T.A. The results have indicated that some of the problems outlined by these critics also appear on the articles analyzed, which shows that critical discourse analysts in Brazil should pay special attention to the way they approach and treat their data.
\end{abstract}

KEYWORDS: critical discourse analysis; criticism; reception; representativeness; research.

\title{
1 Análise Crítica do Discurso: quid pro quo?
}

A Análise Crítica do Discurso (ACD) surge no cenário internacional a partir de algumas publicações de teóricos como Fairclough $(1989,1992)$, van Dijk (1984, 1987, 1988, 1991, 1993), Kress (1985, 1990), Wodak (1990), van Leeuwen (1993), entre outros. A potencialidade dessa disciplina está em sua própria epistemologia, cuja fundamentação sugere que: (i) a linguagem é um tipo de prática social; (ii) os textos resultam de práticas sociais de seus produtores;

\footnotetext{
${ }^{1}$ Esta pesquisa foi apresentada no III Simpósio Internacional de Análise do Discurso, que ocorreu na Faculdade de Letras da UFMG, no período de $1^{\circ}$ a 4 de abril de 2008. Sou grato a meu colega William Menezes (UFOP) pelas sugestôes à primeira versão deste artigo.
} 
(iii) os textos traduzem a desigualdade social em que se situam seus produtores; (iv) os significados textuais expressam-se por meio das interações entre produtores dos textos e seus leitores/ouvintes; (v) os traços linguísticos não são um conjunto arbitrário de formas e significados; (vi) esses mesmos traços linguísticos apresentam discursos ideologicamente camuflados; (vii) os usuários da língua adotam posicionamentos particulares frente ao discurso que produzem; (viii) por fim, a ideologia e as relações de poder, mormente presentes no discurso, tornam-se visíveis por meio de análise textual precisa e acurada.

Wodak (1990) esclarece que o interesse principal da ACD, legatária da Linguística Crítica de Fowler e colegas (1979), é desvelar a injustiça e a desigualdade presentes na naturalização de discursos que representam minorias sociais. Para tanto, Wodak afirma que analistas críticos do discurso devem necessariamente adotar um posicionamento crítico e político em prol dessas minorias, oferecendo-lhes oportunidades de se expressarem em suas pesquisas.

A ACD congrega um conjunto de fatores de análise que procura desvelar relações injustas de poder e construções ideológicas opacas nos discursos produzidos sobretudo pela mídia, fato que mostra claramente sua importância no âmbito das disciplinas das Humanidades e das Ciências Sociais. Widdowson (1996) sublinha essa importância ao afirmar que a contribuição da ACD para os estudos do discurso está justamente no entendimento das relações entre linguagem e sociedade, assim como na compreensão do processo dialético que permeia essas relações.

No entanto, no que tange aos métodos de análise discursiva no âmbito da ACD, por que tem havido tensóes e críticas, por parte de linguistas aplicados e cientistas sociais renomados, como, por exemplo, Henry Widdowson, Michael Stubbs, Michael Toolan, Paul Simpson, Martyn Hammersley, entre outros, acerca das conceituaçóes e procedimentos analíticos usados por essa abordagem? Esses teóricos apresentaram, no contexto internacional, críticas às vezes severas à $\mathrm{ACD}$, alegando, resumidamente, que a referida disciplina não leva em conta os receptores dos textos e que tendenciosamente adota uma postura inicial preconceituosa sobre os textos em geral, levando a interpretaçóes confusas acerca de seu caráter teórico e metodológico. Paul Simpson (1993, p. 7) ilustra muito bem esse quid pro quo:

Considere, por exemplo, a desconstrução da palavra 'tinnie', feita por Hodge e Kress, um termo do inglês australiano para garrafa de cerveja: «garrafas de cerveja, apesar de sua forma fálica e de sua associação com a bebida e a solidariedade masculinas, são classificadas com 
o 'ie' da solidariedade feminina implícita, como objetos seguros do desejo masculino" [HODGE; KRESS, 1988, p. 102].

Não está claro se poderíamos esperar do ie de, por exemplo, junkie [viciado/a] uma carga semântica com o mesmo grau de solidariedade feminina. Ao se extrapolar a teoria da forma fálica da garrafa de cerveja, poder-se-ia concluir que todas as formas cilíndricas apresentam tal formato devido à conspiração sexista masculina, e não porque podem simplesmente ser formas úteis de embalagem de produtos. Há momentos, talvez, que uma garrafa de cerveja é apenas uma garrafa de cerveja. ${ }^{2}$

Para Simpson, tem havido uma supervalorização de posicionamentos ideológicos dos analistas críticos do discurso em suas interpretaçôes, em detrimento de análises mais precisas do que realmente encontra-se presente e claro nos dados investigados. Essa crítica, que a meu ver foi uma das primeiras à $A C D$ no contexto internacional, gerou reflexôes pontuais de um conjunto significativo de teóricos dos campos da Sociologia, da Estilística e da Linguística Aplicada.

Em virtude dessas críticas surgidas de análises de várias publicaçôes da ACD no exterior, neste artigo tenciono analisar o número especial sobre a ACD de um periódico conceituado na área da Linguística Teórica e Aplicada no Brasil, a saber, a revista D.E.L.T.A. ${ }^{3}$ Por entender que esse número especial congrega trabalhos de analistas críticos do discurso brasileiros, farei uma análise dos métodos usados nesses trabalhos empíricos e de seus resultados, a fim de

${ }^{2}$ Minha tradução de: "Consider, for instance, Hodge and Kress's deconstruction of the word 'tinnie', an Australian English term for tin of beer:

"tins of beer in spite of their phallic shape and association with male drinking and male solidarity, are classified with the 'ie' of implicitly feminine solidarity, as safe objects of male desire» [HODGE and KRESS, 1988, p. 102].

It is not clear if the ie of, say, junkie would be expected to carry the same degree of feminine solidarity. Extrapolating from the theory of the phallus-shaped beer tin, one might also conclude that all cylindrical containers were so-shaped because of this male sexist conspiracy and not because they just happen to be a useful way of storing products. There are times, perhaps, when a tin of beer is only a tin of beer." ${ }^{3}$ Por motivo de limite de páginas, neste artigo apenas investigo o número especial da revista D.E.L.T.A. O periódico Linguagem em (Dis)curso também lançou um número especial, em 2004, sobre a ACD. A escolha pela D.E.L.T.A. justifica-se pelo fato de este número ser mais recente (2005) e de o referido periódico ter obtido conceito A na última avaliação da CAPES (Coordenação de Aperfeiçoamento de Pessoal de Nível Superior). 
perceber como os pressupostos da $\mathrm{ACD}$ têm sido aplicados às realidades discursivas do contexto nacional. $\mathrm{O}$ contraponto para esse estudo serão as considerações e críticas realizadas pelo conjunto de linguistas aplicados e sociólogos citados anteriormente, com o objetivo de perceber se os mesmos problemas ecoam nos artigos selecionados para análise.

No que se segue, faço uma resenha sucinta das principais críticas à $\mathrm{ACD}$ feitas por Henry Widdowson (2003), ${ }_{4}^{4}$ Martyn Hammersley (1997), Michael Stubbs (1997) e Michael Toolan (1997). Em seguida, apresento os procedimentos de análise dos dados, os comentários aos artigos empíricos dos periódicos estudados e, por fim, as considerações finais.

\section{Críticas à ACD no cenário internacional}

\subsection{Henry Widdowson: a crítica da recepção}

Em artigo publicado no periódico Language and Literature, intitulado "Discourse analysis: a critical view", Widdowson (1995) se posiciona favorável à $\mathrm{ACD}$, desde que esta tenha bem definida, no âmbito de suas conceituações, a relação entre escopo e engajamento político. Essa relação, ou talvez dicotomia, leva necessariamente, segundo Widdowson, às definiçóes de análise e interpretação. Para esse teórico, essa relação é crucial para a metodologia da ACD, uma vez que direciona o analista ao entendimento do discurso como negociação de sentidos, a partir de sua manifestação em contextos específicos (significado pragmático), e como realização material, por meio de textos, dessa negociação. A noção de sentido é, portanto, dependente do contexto de uso e transformada à medida que se manifesta textualmente.

Widdowson afirma, categoricamente, que os analistas críticos do discurso não fazem análise, mas interpretam discursos presentes em textos. Tal "falácia metodológica" conduz a uma supervalorização de informações presentes nos dados investigados por esses analistas, visto que as intençóes comunicativas de um dado interlocutor só se tornam palpáveis e concretas quando processadas pela outra parte do evento comunicativo, neste caso, o outro interlocutor, ou receptor da mensagem. Em outras palavras, Widdowson salienta que a ACD

\footnotetext{
${ }^{4}$ Esse texto foi originalmente publicado no periódico Language and Literature, em 1995. Neste artigo, faço menção à sua réplica presente na coletânea organizada e comentada por Barbara Seidlhofer, intitulada Controversies in Applied Linguistics, publicada pela Oxford University Press (SEIDLHOFER, 2003).
} 
não realiza, de facto, uma análise da recepção do texto pelo outro interlocutor, o que não permite aos analistas críticos do discurso identificar os efeitos ideológicos que frequentemente eles afirmam estar camuflados nos dados.

Essas ponderações levam Widdowson a dizer que não se pode explicar como as pessoas expressam suas ideologias simplesmente assumindo que essas ideologias estão previamente fixadas na linguagem. Essa é uma postura de mera interpretação, não de análise. Como sugestão de solução para essa "falácia", Widdowson indica a necessidade de um estudo etnográfico da recepção dos textos, a fim de se entender que um texto pode ter determinados sentidos para seu produtor, o que não necessariamente ocorre no processamento da recepção desse mesmo texto por parte do leitor/ouvinte.

A meu ver, as colocações de Widdowson lançam luz sobre os processos de análise de dados não apenas no âmbito da $\mathrm{ACD}$, mas nas pesquisas da Análise do Discurso $(\mathrm{AD})$ em geral, por esclarecerem a distinção entre interpretação e análise. Todavia, embora Widdowson afirme categoricamente que a ACD não faz análise propriamente dita, nos termos por ele explicitados, ele cai em contradição ao ponderar que o caráter sociopolítico da ACD reside na interpretação dos dados, fato que deve ser positivamente considerado no cerne dessa disciplina (WIDDOWSON, 2003, p. 144). Nesse sentido, questiono se as críticas de Widdowson não criariam mais impedimentos metodológicos à $\mathrm{ACD}$ em particular, e à $\mathrm{AD}$ em geral, dos que os já presentes em seu artigo, admitindo-se que uma análise da recepção dos textos é um trabalho não somente hercúleo, mas inviável em algumas instâncias sociais.

Além disso, é comum, em pesquisas de comunicação de massa (ver, por exemplo, BELL, 1991), a realização de questionários de opiniōes, entre outros procedimentos, para serem respondidos por leitores dos media, numa tentativa de apanhar a concepção formada por esses leitores a respeito de determinada notícia. Embora seja totalmente válido esse procedimento de coleta de dados, não há garantia de que das respostas possam emergir padrões ou categorias de análise que apontem seguramente como leitores "entendem" o texto, por dois básicos motivos: (i) cada leitor processa de maneira diferenciada o significado expresso na reportagem, conforme seu conhecimento enciclopédico, seus interesses cognitivos de leitura e sua realidade de mundo, e (ii) a amostragem, por mais representativa que seja, dificilmente expressará um conjunto de informaçōes que garanta generalizações de análise (a esse respeito, ver a crítica de Michael Stubbs mais adiante).

Um ponto que merece destaque na crítica de Widdowson é a abordagem dos dados pelo analista crítico do discurso. Ao invés de adotar uma postura 
crítica prévia em relação aos aspectos ideológicos nos discursos, o que concorreria para a ênfase da parcialidade interpretativa e, consequentemente, para a disseminação de juízos de valor, o analista poderia perceber nos textos os fatos linguísticos que claramente apontassem a opacidade ideológica em sua produção, levantando hipóteses acerca de seu efeito nos receptores dos textos investigados. Para tanto, o analista lançaria mão de teorias da linguagem (por exemplo, HALLIDAY, 1978, 1985, 1994; HALLIDAY; MATTHIESSEN, 2004; FAIRCLOUGH, 2003; van DIJK, 1998; van LEEUWEN, 1996) para a identificação de categorias linguísticas de análise e sua relação com o social e a cultura, e de teorias do contexto e sua relação com a linguagem (por exemplo, DURANTI; GOODWIN, 1992; DURANTI, 1997; FOLEY, 1997), com o objetivo de perceber como a constituição da realidade, por meio do uso da linguagem, guarda relações diretas com a indexação.

\subsection{Martyn Hammersley: a crítica sobre a crítica}

Hammersley (1997), em artigo publicado no periódico Language \& Communication, intitulado "On the foundations of critical discourse analysis", problematiza o uso do epíteto "crítica" no nome da disciplina. Para Hammersley, o significado desse adjetivo recupera uma construção terminológica que remonta à crítica marxista da constituição da sociedade capitalista, cujo fundamento expressa "um abandono de qualquer restrição avaliativa dos textos e dos contextos em que são estudado"” (HAMMERSLEY, 1997, p. 238). Nessa linha de pensamento, esse sociólogo apresenta cinco características que subjazem ao termo "crítico", quais sejam: (i) a sociedade só pode ser compreendida em sua totalidade; (ii) a produção do conhecimento acerca da sociedade revela aspectos ideológicos que se encontram ofuscados; (iii) a crítica social não apenas descreve a sociedade como ela é, mas como ela deveria ser; (iv) a pesquisa crítica deve necessariamente apresentar mecanismos de mudança social; (v) a mudança deve levar à erradicação da opressão e à emancipação dos agentes sociais.

Sustentando-se no argumento de que a noção de criticismo nas Ciências Sociais e nas Humanidades resulta de construçôes históricas do termo ao longo dos séculos dezenove e vinte, Hammersley conclui que a ACD, sobretudo a abordagem defendida por Norman Fairclough, trata o conceito como um fenômeno óbvio, concorrendo, de igual modo, para a falta de problematização

\footnotetext{
${ }^{5}$ Minha tradução de: "an abandonment of any restraint on evaluation of the texts and contexts that are studied".
} 
desse termo no âmbito da própria disciplina. Hammersley coloca que as bases filosóficas da ACD não esclarecem a contento qual o real significado da palavra "crítico" em suas análises, o que leva necessariamente a uma interpretação equivocada dos aspectos ideológicos mormente presentes, porém camuflados, nos discursos. Ou seja, para Hammersley (1997, p. 244), "o termo 'crítico' parece funcionar como um guarda-chuva a qualquer abordagem que queira caracterizar-se como politicamente radical", ${ }^{6}$ sem, no entanto, ser legítimo, devido a variedade de significados que esse conceito pode ter nas Ciências Sociais e nas Humanidades.

A crítica mais severa que Hammersley faz a esse respeito está justamente na simplificação do uso do termo ao se referir às teorias macrossociológicas. Hammersley argumenta que a ACD vislumbra apenas dois aspectos críticos - a existência de opressores e de oprimidos, estes sendo subjugados por aqueles, e uma única relação entre eles - dominação. Para esse sociólogo, a aplicação desses conceitos vai muito além dessa simples relação, dada, sobretudo, sua constituição histórica como ações sociais controversas, visto que representam sistemas políticos que têm se sustentado na formação dos mecanismos ideológicos na esteira de décadas. Essa simplificação, conclui Hammersley, pode levar pesquisadores a supervalorizar seus dados e, consequentemente, interpretá-los à luz de seus próprios juízos de valor.

É fato que os problemas colocados por Hammersley originam-se da crítica da Ciência Política ao conceito de ideologia, uma vez que este se tornou ambíguo no próprio seio das Ciências Sociais. Stoppino (2004) fala do conceito "fraco" de ideologia, que traduz um sistema de crenças políticas, ou seja, "um conjunto de idéias e de valores respeitantes à ordem pública e tendo como função orientar os comportamentos políticos coletivos" (p. 585), em contraposição ao conceito "forte" de ideologia, oriunda da conceituação marxista da "falsa consciência de domínio entre as classes" (p. 585). Nesse aspecto, interpreto a posição de Hammersley em relação à $\mathrm{ACD}$ como uma crítica à definição obscura de qual ideologia tem sido problematizada pelos analistas críticos do discurso, visto que em alguns momentos parece clara a inobservância do historicismo ideológico das ações coletivas nos dados, conduzindo as análises a uma interpretação precipitada e confusa dos mecanismos de opressão que a ACD tenta deixar transparente nos discursos investigados.

${ }^{6}$ Minha tradução de: "... the term 'critical' seems to function as an umbrella for any approach that wishes to portray itself as politically radical". 


\subsection{Michael Stubbs: a crítica da representatividade}

Em seu texto "Whorf's children: critical comments on critical discourse analysis (CDA)", publicado no livro Evolving models of language (RYAN; WRAY, 1997), Michael Stubbs $(1997)^{7}$ pontua que os métodos de coleta de dados e análise textual empregados pela ACD não são claros, restringindo-se quase sempre a fragmentos de textos, tanto originais como traduções, e a interpretações pessoais. Segundo esse linguista aplicado, a ACD precisa esclarecer melhor seus critérios de coleta de dados e desenvolver métodos de análise que levem em conta a recepção dos textos pelos leitores, a partir de procedimentos etnográficos. Em virtude dessas lacunas, Stubbs acrescenta que os analistas críticos do discurso, por partirem de problemas sociais e não dos textos a serem analisados, sabem exatamente o que "pretendem" encontrar nos dados, com base em posicionamentos políticos previamente estabelecidos. Para Stubbs, esse movimento analítico caracteriza aCD como uma abordagem circular, isto é, os dados refletem ideologias já estabelecidas e, concomitantemente, as ideologias buscam dados que as representem.

Há, sem dúvida, uma relação entre essas críticas e as realizadas por Widdowson, de cujas colocações Stubbs inspirou-se para desenvolver seus argumentos. $\mathrm{O}$ aspecto forte da crítica de Stubbs, entretanto, situa-se na questão da representatividade, e é esse ponto que pretendo desenvolver, uma vez que tal aspecto não foi apontado nas críticas de Widdowson e Hammersley.

Michael Stubbs tem estabelecido uma agenda a favor da representatividade nos dados em pesquisas orientadas, sobretudo, pela Linguística de Corpus (STUBBS, 1996, 2002). Em sua crítica, Stubbs (1997) coloca que a ACD não analisa dados suficientes para corroborar as generalizações que ela defende. Por investigar, segundo Stubbs, apenas fragmentos de textos, os analistas críticos do discurso deveriam prestar-se a explicaçôes mais plausíveis acerca dos motivos que os levam a selecionar os dados randomicamente e a organizá-los de modo a extrair interpretaçôes que comprovem as hipóteses aventadas.

Contudo, Stubbs (1996, p. 232), em seu livro Text and corpus analysis, adianta-se a esse respeito:

(...) ainda temos um longo caminho a percorrer no entendimento da natureza dos dados em corpora. Frequentemente, a única pergunta feita

\footnotetext{
${ }^{7}$ Disponível em: <http://www.uni-trier.de/uni/fb2/anglistik/Projekte/stubbs/
} whorf.htm>. Todas as menções a Stubbs (1997) são provenientes dessa fonte. 
sobre os corpora é se eles são representativos de uma dada língua. Mesmo tal pergunta nem sempre é aceita como válida. Alguns linguistas de corpus simplesmente argumentam que não é possível ter uma amostragem representativa de 'uma língua', uma vez que a população dessa amostragem é infinita em extensão, estando em constante mudança. ${ }^{8}$

Há dois fatores de real importância nas colocações de Stubbs que, a meu ver, se aplicam, parcialmente, aos interesses de pesquisa da ACD. No tocante ao primeiro fator, Stubbs (1997) fala do problema da representatividade dos dados nas investigações dos analistas críticos do discurso, mas questiona (cf. STUBBS, 1996) se essa representatividade é, de fato, possível de se atingir. Isso posto, remeto-me ao segundo fator, qual seja, a questão das generalizaçōes. Sem dúvida, quanto menor a representatividade, maior a cautela em relação aos resultados das análises, dadas as condições limitadas dos dados, tanto em quantidade quanto em ocorrência de eventos linguísticos, para a construção de conclusões mais generalizadas. Nesse sentido, a crítica que Stubbs faz à ACD, no que se refere à representatividade, é útil em relação ao segundo fator. Nada impede, todavia, que os analistas críticos do discurso investiguem "fragmentos de textos" e nele explorem os aspectos sociopolíticos constituídos na formação histórica e discursiva representada nesses fragmentos. O que deve ficar claro, porém, são as limitações postas por esse procedimento, no tocante às conclusões da análise. Ou seja,

(...) o advento dos corpora de pequenas dimensões abriu novas perspectivas teóricas e metodológicas de análise de textos originais e suas respectivas traduçôes, preenchendo a lacuna que o conceito de representatividade apresentava quando da investigação de corpora menores. A noção de representatividade, pois, torna-se flexível ao se abrir para as especificidades dos objetivos de pesquisa, para os interesses do(a) pesquisador(a) e, notadamente, para os problemas de pesquisa exequíveis ao seu tamanho. A questão da representatividade, neste enfoque, passa a depender dos interesses que o(a) pesquisador(a) tenciona perseguir em sua pesquisa, levando sempre em consideração

\footnotetext{
${ }^{8}$ Minha tradução de: “... we still have a long way to go in understanding the nature of corpus data. Often the only question asked of corpora is whether they are representative of the language. Even this question is not always accepted as valid. Some corpus linguists argue simply that it is not possible to have a representative sample of 'a language', since the population being sampled is infinite in extent and constantly changing."
} 
que os resultados da mesma serão cada vez mais genéricos e pontuais quanto maior o corpus, tanto em número de ocorrência de palavras quanto de gêneros textuais (RODRIGUES JÚNIOR, 2005, p. 18).

Apresento, na próxima seção, os elementos centrais da crítica de Michael Toolan à ACD, fechando, assim, o conjunto de ponderações sobre a epistemologia e os procedimentos metodológicos dessa disciplina.

\subsection{Michael Toolan: a crítica do posicionamento e da prescrição}

Toolan (1997), em artigo publicado no periódico Language and Literature, intitulado "What is critical discourse analysis and why are people saying such terrible things about it?", segue o mesmo conjunto de críticas apresentado por Widdowson, Hammersley e Stubbs, ao enfatizar que a ACD precisa revisitar alguns de seus mecanismos de análise e, sobretudo, demandar dos textos investigados um número maior de categorias analíticas que mostrem claramente a dominação e a hegemonia nos dados.

Um dos incômodos apresentados por Toolan referentes aos argumentos da $\mathrm{ACD}$ é que esta afirma categoricamente que a $\mathrm{AD}$ tem adotado uma postura acrítica, embora boa parte da base epistemológica da $\mathrm{ACD}$ seja proveniente de teóricos que, de igual modo, sustentam as análises da $\mathrm{AD}$, como são os casos dos conceitos de "ordens do discurso", de Foucault, de "habitus", de Bourdieu, e de "intertextualidade", inaugurado por Bakhtin e expandido por Kristeva. Dando maior ênfase aos trabalhos de Fairclough, Toolan considera que sua pesquisa segue uma linha de pensamento muito próxima da $\mathrm{AD}$, quando das discussões sobre os usos das definições de heterogeneidade discursiva, intertextualidade e interdiscursividade, e de suas manifestações em textos.

Um aspecto da crítica de Toolan à ACD encontra-se no fato de que os analistas críticos do discurso frequentemente abordam os dados como se estes já trouxessem, em sua superfície discursiva, a naturalização de ideologias dominantes e de relações camufladas de opressão e de poder. Essa "postura metodológica preconcebida" leva os praticantes da ACD a conclusões precipitadas sobre os aspectos sociopolíticos que eles professam. Esse procedimento induz os analistas a perceberem que garrafas são símbolos da dominação masculina, e não simplesmente formas práticas de armazenamento de líquidos (a esse respeito, ver comentários no item 1 deste artigo).

No meu entender, a idéia central da crítica de Toolan, que a distingue das críticas resenhadas até então, refere-se ao fato de que os posicionamentos políticos contra a opressão e as relações de poder remontam à Idade Média, 
quando a burguesia estabeleceu limites à dominação do clero e passou a ter o controle da política econômica do século quinze. Já no pensamento contemporâneo, a burguesia adquiriu uma conotação distinta de sua origem, a partir da interpretação marxista, na qual

[a] Burguesia, pois, seria a classe que detém (...) os meios de produção e que, portanto, é portadora do poder econômico e político. Seu oponente seria o proletariado que, desprovido destes meios, possui unicamente sua força de trabalho (BRAVO, 2004, p. 119).

Isso significa dizer que a ACD precisa adotar posicionamentos cujas bases privilegiem a construção histórica das relações de poder e de hegemonia, em que, como afirmou Hammersley (1997), não existe apenas relaçóes dicotômicas e simplistas entre dominadores e dominados, mas, especialmente, um conjunto de fatores políticos, econômicos e sociais que tipifica essas relações, dando-lhes formas multivariadas conforme suas manifestações sociais no decorrer da história.

Nesse sentido, pensar os discursos como materializações dessas relações implica compreender a vida social também como um fenômeno híbrido, no qual novas formas de dominação emergem à medida que novas e variadas formas textuais surgem para representá-las materialmente. Nesse ponto, Toolan destaca a importância da ACD para o entendimento dessas relações, embora os analistas críticos do discurso raramente apresentem possibilidades de mudança social a respeito dos problemas por eles investigados. Com efeito, Toolan conclui seu artigo enfatizando que a ACD não pode recear prescrever mecanismos de correção e reforma de discursos hegemônicos existentes, como tem ocorrido nas pesquisas de seus seguidores.

\section{Procedimentos de análise}

Os procedimentos de análise adotados neste trabalho são de caráter descritivo, com o objetivo de analisar o conteúdo dos artigos empíricos publicados no número especial da revista D.E.L.T.A. que versa sobre a ACD. No caso deste artigo, o estudo das pesquisas desenvolvidas nesse periódico de circulação nacional e internacional tem como critério as seguintes etapas: (i) a caracterização das pesquisas em ACD realizadas pelos autores dos artigos; (ii) os procedimentos metodológicos utilizados; (iii) as conclusões aventadas a partir das análises feitas. O contraponto para a análise do conteúdo (cf. BARDIN, 2004) dos trabalhos serão os argumentos apresentados pelo 
conjunto de teóricos resenhados anteriormente. Pretende-se, neste artigo, identificar, observar e descrever as formas de análise do corpus selecionado, na tentativa de perceber se há ressonância das críticas feitas no cenário internacional nos dados investigados. Para tanto, a análise se divide em três momentos: (i) a questão da teoria; (ii) a questão do método; (iii) a questão da análise. Por fim, ressalto que somente os artigos empíricos, escritos em língua portuguesa, foram analisados, porque investigam fenômenos discursivos oriundos de eventos ocorridos no Brasil.

\section{Análise dos artigos da revista Documentação de Estudos em Linguística Teórica e Aplicada (D.E.L.T.A.)}

O número 21, de 2005, da revista D.E.L.T.A., publicada pelo Programa de Estudos Pós-Graduados da Pontifícia Universidade Católica de São Paulo (PUC-SP), apresenta quatro artigos empíricos, de caráter crítico-discursivo, cuja orientação de análise se sustenta nos postulados epistemológicos da ACD. $\mathrm{Na}$ apresentação do número especial, Izabel Magalhães (2005, p. 7) adiantase a esse respeito: "[u]ma palavra final sobre o processo de seleção dos autores incluídos neste número especial. O contato inicial foi feito com 16 pesquisadores, no Brasil e no exterior, todos praticantes da ADC. ${ }^{9}$ O que se segue é produto de um trabalho de dois anos". Para fins de maior facilidade de análise e referenciação textual, doravante nomeio os artigos analisados nesta seção como DELTA 1, DELTA 2, DELTA 3 e DELTA 4. Seguem, entretanto, os títulos e autores dos referidos artigos: DELTA 1 tem como título "O discurso jornalístico sobre privatizações e protestos nas ruas", cuja autora é Maria Christina Diniz Leal (LEAL, 2005), da Universidade de Brasília; DELTA 2 tem como título "Motivações cognitivas e interacionais em competição: a força das palavras em contexto", cuja autora é Denize Elena Garcia da Silva (Silva, 2005), da Universidade de Brasília; DELTA 3 tem como título "Grupos excluídos no discurso da mídia: uma análise de discurso crítica”, cujo autor é

\footnotetext{
${ }^{9}$ Tem havido controvérsias acerca da tradução do termo Critical Discourse Analysis para o português. Seguindo a adjetivação "critical" do substantivo "discourse analysis", o grupo de pesquisadores da Universidade de Brasília, orientados por Izabel Magalhães, adota o título Análise do Discurso Crítica (ADC). Outros grupos de pesquisa na área, como é o caso, por exemplo, de pesquisadores da Universidade Federal de Santa Catarina, adotam o título Análise Crítica do Discurso (ACD). Prefiro este título ao anterior, por traduzir a idéia central da disciplina - um enfoque crítico e social às análises de discursos variados.
} 
André Ricardo Nunes Martins (MARTINS, 2005), da Universidade de Brasília; por fim, DELTA 4 traz como título "Discurso como arma de guerra: um posicionamento ocidentalista na construção da alteridade", cujos autores são Luiz Paulo da Moita Lopes e Branca Falabella Fabrício (MOITA LOPES; FABRÍCIO, 2005), ambos da Universidade Federal do Rio de Janeiro.

\subsection{A questão da teoria}

Todos os artigos dizem-se afiliados à $\mathrm{ACD}$, como pode ser constatado na fundamentação teórica que eles trazem:

\section{DELTA 1:}

A pesquisa de que trata este artigo teve como base teórica a obra de Chouliaraki e Fairclough (1999) que propōem um repensar sobre a análise de discurso critica, na perspectiva da modernidade tardia (LEAL, 2005, p. 74).

\section{DELTA 2:}

As reflexóes aqui registradas procedem de postura crítica tomada dentro da análise do discurso vista não só como corrente linguística, mas, também, como método de estudo. A análise do discurso que enfoca a língua como prática social constitui meu passaporte teórico, e o discurso - concebido como modo de ação das pessoas (sobre o mundo e sobre outras pessoas), bem como uma forma de representação de significação (que constitui e constrói o mundo), como propóe Norman Fairclough (2001) - embasa o escopo do artigo, cujo objetivo central é explicitar as motivaçóes cognitivas e interacionais que costumam ocorrer no espaço da sala de aula (SILVA, 2005, p. 94).

\section{DELTA 3:}

Esta pesquisa alinha-se, portanto, com essa perspectiva expressa por Fairclough. Dai porque investem em análise do texto, não apenas análise do discurso em seus aspectos mais abrangentes ou mesmo dos enunciados, mas, sim, o exame das próprias estruturas de um determinado texto. Nessa perspectiva, a ADC propóe-se a encetar uma análise linguistica propriamente dita como suporte de uma análise do processo discursivo. Valoriza-se, portanto, uma especificidade linguistica nessa visão do discurso (MARTINS, 2005, p. 135).

DELTA 4:

Cabe lembrar que o olhar que orienta nossa argumentação filia-se à teorização pós-colonial no sentido de que entendemos a necessidade de 
repensar uma série de significados construidos sobre a diferença, que eram parte do mundo colonial, em sua voracidade de ocidentalizar ou levar a modernidade ao mundo não-europeu (MOITA LOPES; FABRÍCIO, 2005, p. 241-2).

(...)

Como analistas do discurso afinados com o pensamento pós-colonial, entendemos o nosso fazer como uma prática problematizadora (Pennycook 2001), que, operando em um constante movimento interrogador, estranha sentidos cristalizados e afasta-se das construçôes sólidas e das certezas pantanosas do conhecimento (MOITA LOPES; FABRÍCIO, 2005, p. 242-3).

(...)

Em razão dessa ótica, encorajamo-nos a utilizar as ferramentas analíticas da ADC para a compreensão da produção de identidade e diferença no discurso da mídia. (MOITA LOPES; FABRÍCIO, 2005, p. 257).

Um aspecto notório nos excertos são os variados tipos de escopo que as propostas dos artigos apresentam. Descritores como "modernidade tardia", "corrente linguística", "representação de significação", "análise do texto", "teorização pós-colonial", "ferramentas analíticas da ADC", entre outras, tipificam a ACD como disciplina com escopo variado e amplo. Segundo os excertos, os analistas críticos do discurso têm em mãos um conjunto de "ferramentas analíticas" para tornar clara a opacidade dos discursos investigados nos artigos em foco. Essa variedade de escopos posta pela ACD leva naturalmente a métodos analíticos distintos, em que se privilegiam procedimentos de análise que respondam satisfatoriamente às perguntas de pesquisa específicas de cada artigo. Essa variedade indica que os métodos da ACD dependem muito mais dos objetivos do analista do que de uma uniformização de procedimentos que caracterize a disciplina, como acontece com análises nos âmbitos da Sociolinguístisca Variacionista, da Sociolinguística Interacional, da Análise da Conversa, da Linguística Textual, da Linguística Sistêmico-Funcional, entre outras. Pela análise das palavras-chave dos excertos citados anteriormente, percebemos ênfases diferentes no que tange ao escopo da pesquisa apresentada em cada artigo, embora todas estejam sob o guardachuva de uma única disciplina - a ACD.

Essas características encontram ressonância nas críticas apresentadas sobretudo por Widdowson (2003), quando este linguista aplicado afirma que o escopo da ACD se confunde com partidarismos políticos e posicionamentos ideológicos. É fato que a ausência de procedimentos metodológicos concretos, colocada pela variedade de abordagens dos analistas críticos do discurso, aponta 
para uma confusão de usos das "ferramentas analíticas" que mais traduzem os interesses do analista do que uma uniformização de métodos pertinentes aos propósitos da ACD. Há, no entanto, controvérsias em relação a esse 'problema metodológico', uma vez que os propósitos da ACD se fundamentam numa visão crítica e pós-moderna acerca dos discursos constituídos por práticas sociais, sendo os próprios discursos momentos constitutivos dessas práticas (cf. CHOULIARAKI; FAIRCLOUGH, 1999). Isso indica que a análise de fenômenos sociais típicos da modernidade tardia implica necessariamente a observação, decodificação e interpretação de fenômenos dentro de um espectro semiológico mais amplo, desde a significação textual até linguagens visuais que 'representam' discursos hegemonicamente constituídos ao longo da história. Embora os procedimentos metodológicos devam ser claros, como argumenta Widdowson, limitá-los a procedimentos estanques pode ofuscar os propósitos de análise da ACD.

\subsection{A questão do método}

Com relação aos artigos da revista D.E.L.T.A., os procedimentos metodológicos são distintos entre si, por traduzirem os interesses de análise de seus autores. Outro aspecto salientado pela maioria das críticas apresentadas na segunda seção deste artigo, especialmente por Stubbs, é o problema da representatividade dos dados. Em todos os artigos do referido periódico, os dados são de pequena dimensão.

\section{DELTA 1:}

O corpus analisado constitui-se de reportagens e editoriais sobre três leilóes para a privatização de companhias estatais brasileiras e sobre os protestos. (...)

Selecionei dois jornais de prestígio nacional, por serem editados nos centros urbanos formadores de opiniāo do pais: Jornal do Brasil (Rio de Janeiro) e Folha de São Paulo (São Paulo). O critério de seleção dos outros dois jornais foi o de serem editados em Brasilia, capital da república e sede dos três poderes do pais: Correio Braziliense e Jornal de Brasilia (LEAL, 2005, p. 78-9).

É curioso observar nesse excerto o caráter excludente da justificativa pela seleção dos dados de análise: o Jornal do Brasil e a Folha de S.Paulo são considerados jornais formadores de opiniāo, oriundos, respectivamente, das metrópoles do Rio de Janeiro e de São Paulo. No entanto, cabe questionar por que outras metrópoles brasileiras não poderiam exercer esse mesmo papel social, isto é, formar opiniões. 
O outro "critério de seleção" foi o fato de os jornais Correio Braziliense e Jornal de Brasília representarem opiniōes de cidadãos da capital da república. O recorte feito exclui vozes de outras regiōes do Brasil que também disseminam ideologias e juízos de valor em pé de igualdade com os jornais do circuito RioSão Paulo-Brasília. Cabe então o questionamento, ecoando as argumentaçôes de Stubbs: até que ponto os dados extraídos desses quatro jornais representam discursos que ilustram a opinião brasileira a respeito das privatizaçôes? Esse corpus é representativo o suficiente para retratar uma realidade nacional? $\mathrm{O}$ problema da representatividade também pode ser visto em DELTA 2:

\section{DELTA 2:}

Os dados que compõem esta seção envolvem três episódios que foram gravados em vídeo durante uma aula sobre composição de textos, impartida por um professor de redaçāo para uma turma formada por jovens, alunos de terceiro ano do segundo grau de uma escola pública, situada em uma cidade satélite próxima a Brasília (SILVA, 2005, p. 98).

A autora do artigo adianta-se, afirmando categoricamente que "a situação social-comunicativa ilustrada na interação dialógica assimétrica que se desenvolve entre o professor e alguns alunos revela, já de início, a ausência de ação pedagógica de controle ou monitoramento de classe" (p. 98). Cabe novamente um questionamento acerca da representatividade dos dados da pesquisa da autora - é possível posicionar-se negativamente, em relação ao monitoramento do professor sobre seus alunos, apenas fazendo menção a "três episódios" gravados pela pesquisadora? Esses episódios refletem o modus operandi da classe ao longo de um ano letivo? No decorrer da análise dos dados, a autora é taxativa ao apresentar o despreparo do professor tanto em relação ao conteúdo da aula (produção de textos dissertativos), como em relação ao controle da disciplina. Fica evidente, em suas análises, que a autora adotou uma postura crítica preconcebida, supervalorizando, assim, seus pontos de vista, conforme os críticos da $\mathrm{ACD}$, uma vez que os dados não são representativos para declinar opiniōes tão negativas e gerais sobre o professor e seus métodos de ensino.

Dando continuidade aos procedimentos metodológicos utilizados pelos autores dos artigos, vejamos como se posiciona o autor de DELTA 3:

\section{DELTA 3:}

Nesta seção, vamos examinar a representação no discurso da mídia de três segmentos da população brasileira - os índios, os negros e os meninos de rua - historicamente excluídos. 
Como será visto adiante, no processo discursivo da mídia, a escolha lexical, o uso de figuras de linguagem, a intertextualidade, o pressuposto e o implícito aliados a estratégias discursivas como o apagamento de sentidos e a modalização constroem um determinado modo de representação de índios, negros e meninos de rua.

Escolhemos seis textos ilustrativos para análise neste trabalho. Dois para cada segmento excluído. Dos textos referentes aos índios, o primeiro (I - i) é uma reportagem do jornal Correio Braziliense (Assurini fecham rodovia no Pará, 22/04/99) e trata do protesto de um grupo de índios que fecharam o tráfego numa rodovia federal no interior do Estado do Pará como forma de chamar a atenção para as reivindicações da tribo. A reportagem descreve a situação, informa sobre os antecedentes e, ao final, encaminha para a gravidade do problema. O segundo texto (I - ii) é uma reportagem do jornal $\mathrm{O}$ Globo (Índio agora não quer mais apito, quer é educação - Professores da aldeia, treinados por governos e ONGs, alfabetizam na língua materna e em português ao mesmo tempo, 18/04/99) que aborda uma novidade na política educacional do país voltada para comunidades indígenas, o ensino concomitante da língua portuguesa e da língua materna. A matéria analisa a política de ensino e veicula a opinião de professores indígenas e autoridades governamentais.

Dos textos referentes aos negros, um deles (II - iii) é uma reportagem do jornal O Globo (Remanescentes de um quilombo perdido conquistam a posse da terra em Paraty - Comunidade de descendentes de escravos recebe hoje o título de propriedade, 21/03/99) e fala de uma comunidade de descendentes de escravos negros que recebeu o título de propriedade das terras que ocupavam há mais de 150 anos. No texto, como se verá, os negros figuram como beneficiários de uma política social resultante de um dispositivo da Constituição de 1988 - o direito à terra para comunidades remanescentes de quilombos. $\mathrm{O}$ outro texto (II - iv) é uma reportagem do Jornal do Brasil (Contra o racismo - Deputado acusado de discriminação poderá ser cassado, 10/ 02/99) sobre um caso de racismo envolvendo um deputado federal e um co-piloto de uma companhia aérea. Por ofensa de cunho racista, feita ao co-piloto, o deputado federal que viajava de São Luís para tomar posse em Brasília chegou a ser preso em flagrante. A matéria explora o andamento do processo, complexo - por envolver um parlamentar.

Finalmente, dos textos que abordam a questão dos meninos de rua, o primeiro (III - v) é uma reportagem veiculada pelo Jornal do Brasil (A morte ronda os menores carentes - Estatísticas revelam que desde 86 foram assassinadas no Rio mais de 7 mil crianças, 24/01/99) que analisa o crescimento da violência contra crianças e adolescentes no 
estado do Rio de Janeiro, com dados estatísticos da situação. Já o segundo (III - vi) é uma reportagem do Jornal do Brasil (Programa chamado tolerância - Trabalho de liberdade assistida para menores infratores tem 200 voluntários, 07/03/99) que aborda uma nova política de tratamento de meninos e meninas de rua infratores, adotada pela Prefeitura de Belo Horizonte.

A seguir, são apresentados e discutidos alguns enunciados extraidos de textos sobre esses segmentos (MARTINS, 2005, p. 140-1).

O excerto descreve claramente as categorias de análise que o autor pretende explorar em seus dados, a saber: "a escolha lexical, o uso de figuras de linguagem, a intertextualidade, o pressuposto e o implícito aliados a estratégias discursivas como o apagamento de sentidos e a modalização". Essas categorias são frequentemente usadas por analistas críticos do discurso porque expressam, por meio da linguagem, a carga semântica que constrói relações de poder nos discursos (escolhas de itens lexicais que expressam relaçôes hegemônicas, por meio do apagamento do sentido textual e sua consequente ressignificação) e, ao mesmo tempo, disseminam ideias que representam opiniōes de classes dominantes. Essas categorias também convocam outros discursos para formarem redes de significados (intertextualidade), usando, entre outros elementos, o contexto como fonte primária para a formação dessa teia de sentidos (a esse respeito, ver, por exemplo, FAIRCLOUGH, 2001; MARTIN, 2000; WODAK; REISIGL, 2001). Até o momento, DELTA 3 foi o único artigo que apresentou categorias de análise de dados, justificando e explicando cada uma em sua parte teórica. Percebe-se então que os dados serão analisados tendo em vista essas categorias e que seus resultados possivelmente irão depender das formas pelas quais o autor irá interpretá-los.

O trecho em análise também apresenta o corpus a ser investigado de forma clara. É interessante identificar nesse trecho que o conjunto de textos surge de jornais de ampla divulgação no Brasil - Correio Braziliense, O Globo e Jornal do Brasil. As matérias analisadas apresentam notícias do Rio de Janeiro, Belo Horizonte e Pará, o que indica uma abrangência um pouco maior, se comparada ao corpus de DELTA 1, que igualmente investiga reportagens de jornais. Mesmo assim, o corpus de DELTA 3 ainda não pode ser considerado representativo, porque explorou seis textos com o propósito de retratar realidades vividas pelos índios, negros e meninos de rua, grupos "historicamente excluídos". Ademais, como coloca o autor de DELTA 3, apenas alguns enunciados, escolhidos randomicamente, foram analisados, sem 
a devida explicação da motivação que levou o autor a escolher tais enunciados em detrimento de outros.

A questão da representatividade também é questionada em DELTA 4:

\section{DELTA 4:}

$\hat{E}$ com base nesse universo conceitual e no ângulo historicista apresentado nas partes 2 e 3 que nos voltamos, a seguir, para a análise do texto do jornalista Nelson Ascher (em anexo) com vistas à observação de quais discursos sobre a diferença circulam neste exemplo retirado do contexto midiático quando se faz, cada vez mais, a crítica aos discursos da modernidade em um mundo pós-colonial. Duas questôes orientaram o nosso olhar: como o artigo opinativo de autoria do referido jornalista contribui para a articulação da ordem do discurso da midia? Como os recursos da ordem do discurso da midia são utilizados interacionalmente na construção de um ponto de vista ocidentalista? (MOITA LOPES e FABRÍCIO, 2005, p. 259).

O corpus selecionado pelos autores de DELTA 4, intitulado "É hora de reeducar o mundo islâmico", de autoria de Nelson Ascher, colunista da Folha de S.Paulo em Paris, é de pequena dimensão. O texto expressa a opinião pessoal do colunista, cuja argumentação fundamental, colocada pelos autores do artigo, se sustenta num posicionamento norte-americano de inibição total da ameaça islâmica ao mundo ocidental e de consequente ocidentalização do Islá. Ao analisar as duas questões postas pelos autores de DELTA 4, questôes que, segundo eles, orientaram seu olhar interpretativo, vemos duas palavras-chave: "ordem do discurso da mídia", baseada nas teorias de Michel Foucault, e "ponto de vista ocidentalista". Tendo como orientação essas perguntas, fica evidente, com efeito, a generalização que permeou a análise, valendo-se, para tal, de um único texto, significativamente pequeno. Em outras palavras, apreender o "ponto de vista ocidentalista" e a articulação da "ordem do discurso da mídia”, através da análise de um único texto, é inviável. Novamente as colocaçōes de Stubbs (1997) advertem que os analistas críticos do discurso adotam métodos analíticos, até certo ponto, nebulosos, restritos a fragmentos textuais que mostram elementos pertinentes ao texto sob análise, o que de fato não expressa visões generalizadas acerca do fenômeno em pauta.

\subsection{A questão da análise}

DELTA 1 adota a metodologia desenvolvida por Chouliaraki e Fairclough (1999) para analisar seus dados. Essa metodologia, segundo a autora 
do artigo, congrega os seguintes estágios: (i) identificação de um problema social; (ii) identificação da pertinência do problema às necessidades sociais e seus obstáculos; (iii) identificação das possíveis soluções ao problema; (iv) e, por fim, reflexão crítica acerca das propostas de solução do problema apresentadas. Para levar a cabo sua análise, a autora de DELTA 1 investiga a conjuntura em que se situa o problema e os discursos por ele constituídos. A autora assim se coloca diante de seus dados:

\section{DELTA 1:}

Para a defesa da privatização, os editoriais apresentam vários argumentos que apontam o progresso que o país terá e os beneficios para a economia, para a área social e a moralização do estado. Apresentarei a seguir alguns argumentos e comentarei os recursos linguisticos que me pareceram relevantes (LEAL, 2005, p. 82).

A análise dos dados em DELTA 1 reflete uma postura interpretativa, como sustenta Widdowson (2003), e não analítica. Isso é claramente visível pela seleção randômica dos "argumentos" e "recursos linguísticos" feitos pela autora de DELTA 1 - "Apresentarei a seguir alguns argumentos e comentarei os recursos linguísticos que me pareceram relevantes" (grifos meus). Após analisar vinte e seis excertos esparsos, escolhidos sem qualquer critério mais específico, a autora conclui:

\section{DELTA 1:}

O problema em foco, como foi visto, diz respeito à produção do texto no discurso jornalístico e, além disso, diz respeito à leitura, à compreensão dos sentidos do texto. Quanto à produção, existe a pressão dos que detêm o poder, que se mobilizam e se articulam em luta para a hegemonia de suas idéias e posiçōes no poder. A transformação dessa conjuntura depende de profundas e amplas mudanças estruturais. Mas quanto à leitura, já existe uma orientação de ênfase à leitura crítica, à reflexão sobre questōes de discriminação e preconceito presentes na linguagem. Sobre este assunto, cabe mencionar que, nos Parâmetros Curriculares Nacionais - PCNs, entre os objetivos gerais para o Ensino Fundamental, destacam-se: compreender a cidadania como participação social e política, adotando atitudes de solidariedade, cooperação e repúdio às injustiças; questionar a realidade, utilizando para isso a capacidade de análise crítica.

Mas entre os professores de português há dúvida e insegurança quanto a como desenvolver práticas que possam tornar esses objetivos uma realidade. E penso que é ai que fica muito clara a contribuição que a ADC oferece, 
por reunir uma teoria e uma metodologia de leitura e análise que não só visam a explicitar o que é velado, desvendar as relaçóes de poder presentes nos diferentes tipos de discursos, entre eles os discriminatórios, mas também apontam para a transformação (LEAL, 2005, p. 90-1).

A autora convoca o discurso dos Parâmetros Curriculares Nacionais para respaldar suas análises, discutindo a questão do desenvolvimento da leitura crítica no ensino fundamental. Ao apontar para a necessidade de sistematização de uma leitura orientada pela postura crítica, a autora não define o que ela entende por leitura crítica - seria uma leitura opinativa, com juízos de valor e posicionamentos ideológicos? O que vem a ser o epíteto $c r i ́ t i c a$, no que tange às formas de leitura que precisam ser desenvolvidas nas escolas? Entende-se aqui leitura crítica tal qual a realizada pela autora, a partir de escolhas randômicas de trechos em que as relaçóes de poder e os discursos hegemônicos estão instaurados? Um exemplo de análise de DELTA 1 pode clarear melhor meus questionamentos:

\section{DELTA 1:}

(26) Precisamos ter em mente que os inimigos da privatização parceiros do atraso - são numerosos e dispōem de muita força. (...) São três os adversários do processo de desestatização: as corporações, setores do empresariado e os partidos políticos e entidades sindicais que professam ideologias ultrapassadas. (J de Br-ed-25/10/91)

Como se vê, são itens lexicais com uma forte carga apelativa, mobilizadora de uma posição de resistência e ataque aos manifestantes. Por que inimigos e não opositores? $\mathrm{O}$ forte poder apelativo é construído também por meio do nós inclusivo em precisamos; da modalização de obrigatoriedade em precisamos ter e por meio da afirmação categórica em São três os adversários.

Por meio das três análises desenvolvidas, evidenciam-se as dificuldades para que a imprensa se torne realmente imparcial e democrática, assumindo a função pública que lhe compete. $\mathrm{Na}$ conjuntura dos três leilóes, pode-se perceber a atuação dos grandes grupos econômicos que se mantiveram coesos e fortes por meio de alianças. Ficou bem claro que o discurso da imprensa sobre as privatizaçōes e as manifestaçōes de protesto internalizou outros momentos da prática de produção - as crenças dos grupos hegemônicos nas vantagens da privatização; o poder desses grupos exercido por meio de mecanismos ideológicos de legitimação e marginalização dos opositores. E isto se deu pela construção de um interdiscurso, em que as ordens de discurso da imprensa, da política, da literatura se articulam por meio da articulação dos gêneros informativo, persuasivo e literário, em que predomina a 
força argumentativa. Cria-se desse modo, junto à opinião pública, a idéia da necessidade premente da privatização e uma identidade altamente negativa dos manifestantes, principalmente sindicalistas. Além disto, constroi-se também uma relação negativa entre o público leitor e esses manifestantes.

Esse tratamento dado pela imprensa ao movimento sindical é compreendido quando se leva em consideração os interesses econômicos presentes na produção de um jornal (LEAL, 2005, p. 89-90).

Embora a autora tenha claramente identificado os elementos linguísticos (itens léxico-gramaticais) que potencialmente traduzem formas ideológicas de figuração do problema das privatizaçóes, ela parece não levar em conta o processo de produção do texto jornalístico. Além da supervalorização do uso da palavra crítica, sem a devida explicação de sua constituição história no contexto midiático (cf. HAMMERSLEY, 1997), a autora não explora os mecanismos interativos de produção do texto jornalístico, desde sua escrita pelo jornalista, até suas múltiplas revisões realizadas pelo editor-chefe e pelo sub-editor, com o objetivo de atender ao estilo do jornal (cf. BELL, 1991; STUBBS, 1997). Vemos então que a autora resvala em dois problemas colocados, respectivamente, por Hammersley (1997) e Stubbs (1997): o que é criticismo na $\mathrm{ACD}$ e que influências as formas de produção do texto jornalístico exercem na circulação de suas informações? Ao tentar esclarecer as controvérsias no entorno da produção desse gênero textual, a autora se baseia nos "interesses econômicos presentes na produção de um jornal". Essa assertiva, além de lacônica, pouco contribui para respaldar os argumentos da análise realizada em DELTA 1, tornando-a, de acordo com Stubbs (1997), circular, isto é, os dados refletem ideologias já estabelecidas e, concomitantemente, as ideologias buscam dados que as representem.

As análises de DELTA 2 são exemplos claros de generalização, tal qual discutiu Stubbs (1997). Partindo da análise de três episódios de interações de sala de aula de língua materna, a autora de DELTA 2 afirma que há uma ausência de monitoramento do professor sobre seus alunos, causada pelo processo interativo típico da sala de aula.

DELTA 2:

(...) observemos o episódio (1), que ilustra como as motivaçōes cognitivas e interacionais podem ser identificadas por meio do discurso visto como prática social. $\mathrm{O}$ professor $(\mathrm{P})$, anunciando para os alunos (A1, A2, A3 e outros) que falará sobre o tema "dissertação", inicia a aula: 
EPISÓDIO 1: Caracterizando o gênero dissertativo

P: Bom, normalmente... a dissertação é entendida... estão acompanhando, não é mesmo?

((A turma conversa.))

A1: Vai ter aula?...

P: Vou te dar uma página pra estudar...

( $(\mathrm{O}$ professor se dirige à aluna que tentou interromper sua fala com uma brincadeira))

P: Xá mi vê:: a introdução é o prenúncio du que será discutidu, argumenta.../como se diz o::sei lá... introdução é pra introduzir... Vamos lá?... desenvolvimento...o desenvolvimento é a argumentação. Eu estou falando, argumentando com vocês....

((Tom de censura, já que a turma conversa.))

P: Bom, agora vou explicar, pode ser?... a turminha aí do fundo... posso explicar, posso explicar?... É assunto de prova... Pensem na nota...Cida, Cida... senta aí!...

((A aluna se aquieta meio constrangida.))

P: Sim, é preciso tê argumentu, se posicioná a favor ou contra. No fundo, no fundo, esse posicionamento... Oi, ô:: Carlos... isso irrita, né?... tá atrapalhando...

((Impaciência evidenciada no tom de voz do professor))

P: Quando nós nos posicionamos a favô ou contra, por exemplo... a carteirinha da escola, ou melhor, a caderneta ...você é a favô ou contra?... A caderneta é um documento que a escola utiliza pra controlar a frequência dos alunos e assim poder acompanhar esse aluno mais de perto.

O episódio em destaque permite identificar momentos de um processo interacional em que os gestos comunicativos aparecem impregnados de significados os quais, por sua vez, sinalizam de maneira clara o que provoca, por exemplo, a atitude da aluna (A1) que interrompe a fala do professor (P). Sabe-se que, no processo de interação, levamos conosco os atributos que conquistamos. E, em uma situação de sala de aula, são justamente esses atributos que contribuem para fortalecer a autoridade de um professor ao exercer o seu papel social na ação pedagógica. $\mathrm{O}$ episódio em questão evidencia que o professor não detém conhecimento suficiente para transmitir com clareza, pelo menos durante aquela aula, o que vem a ser uma dissertação. Se todo ato de fala é um índice de identidade, os dados em análise permitem inferir que a fala do professor colide, no caso, com o seu papel social de detentor do saber. Isso implica desvio nas expectativas ou nos modelos mentais que se tem da imagem docente. $\mathrm{E}$, aos alunos mais jovens, isso não passa de largo. Daí a pergunta, quiçá matizada de ironia, da aluna: - Vai ter aula? 
Por outro lado, mais que um gesto comunicativo matizado de ironia, podese ponderar que o fato de o professor revelar atitude insegura, durante a exposição de um tema, gerou a motivação que provocou a conduta não só da jovem, mas também de seus colegas que conversavam apesar dos apelos do professor (SILVA, 2005, p. 98-100).

Após algumas tentativas de explicar o "episódio em destaque", a autora de DELTA 2 afirma que "[o] episódio em questão evidencia que o professor não detém conhecimento suficiente para transmitir com clareza, pelo menos durante aquela aula, o que vem a ser uma dissertação." A partir das críticas apresentadas anteriormente, com base em quais critérios analíticos a autora pode declarar a falta de conhecimento do professor sobre o tema 'dissertação'? Embora a autora advogue em seu artigo que o contexto tem papel fundamental na dinâmica das interações de sala de aula, em suas análises não houve a consideração do contexto como fato gerador dos problemas enfrentados pelo professor ou colaborador de sua pesquisa, tais como, indisciplina. Parece-me que a autora de DELTA 2 é a favor do papel do professor como alguém que deve controlar, monitorar e se responsabilizar pelo comportamento irreverente de seus alunos, além de transmitir conhecimento e garantir o aprendizado, mesmo que os alunos não cooperem para que esse processo aconteça realmente. Mais uma vez, as análises feitas não passam de mera interpretação, como apontou Widdowson (2003), disseminando juízos de valor acerca da prática pedagógica do referido professor.

A autora de DELTA 2 conclui:

\section{DELTA 2:}

[a] análise dos dados colhidos dentro de um espaço ecológico por excelência, ou seja, o âmbito de sala de aula, sugere que as atitudes dos falantes constituem aspecto fundamental. Trata-se de categoria que permite identificar, através das práticas discursivas e sociais refletidas nos usos linguisticos, a competição de motivaçôes cognitivas e interacionais quando a realidade do momento compartilhado dentro de sala de aula fugir às expectativas, ou "experiência", de cada interlocutor (SILVA, 2005, p. 102).

Além de obscura e pouco elucidativa, a conclusão de DELTA 2 não retoma os elementos fundacionais de sua crítica, nem tampouco apresenta argumentos que mostrem claramente as relações de poder supostamente presentes na interação (as)simétrica entre o professor e seus alunos. $\mathrm{O}$ artigo, portanto, não passa de mera interpretação, com ênfase no posicionamento pessoal de sua autora. 
Seguindo padrões de análise semelhantes aos vistos até agora, DELTA 3 questiona as relações de poder em torno das minorias sociais - índios, negros e meninos de rua. A título de exemplificação, o excerto a seguir mostra o estilo interpretativo do autor de DELTA 3, que se repete em todas as análises do referido artigo:

\section{DELTA 3:}

(I - i) "E para completar, o protesto dos índios ganhou o apoio do Movimento dos Trabalhadores Rurais Sem-Terra (MST) na região." O enunciado em questão começa pela conjunção aditiva "e", seguida pela expressão "para completar". A construção é muito comum em situações de fala ou escrita como recurso linguístico de reforço para algo muito importante que se segue imediatamente. Nesse caso, o ponto alto é a associação estratégica entre índios em protesto e um Movimento conhecido nacionalmente pela capacidade de luta por reforma agrária.

A associação entre os dois grupos ganha mais dramaticidade uma vez que lá mesmo no Pará, três anos antes, um protesto do MST também resultou num bloqueio de rodovia. $\mathrm{O}$ fato inclusive é explorado pelo texto em outra situação em que mostra o cuidado da polícia para evitar uma intervenção precipitada.

Em $(I-i)$, o que emerge é uma prevenção contra movimentos de reivindicação. O texto é construido do ponto de vista da sociedade, excluindo, porém, os grupos sociais que reivindicam direitos. Dai porque a relevância que é dada no texto não é tanto a questôes como justiça e verdade dos fatos. Não se ouve a resposta do governo à reivindicação do grupo. $O$ foco éo incômodo e a anormalidade que o bloqueio de uma estrada traz aos usuários (MARTINS, 2005, p. 141-2).

Após descrever a construção textual do trecho (I - i), o autor de DELTA 3 diz que desse trecho emerge "uma prevenção contra movimentos de reivindicação"; além disso, o texto sob análise foi "construído do ponto de vista da sociedade, excluindo, porém, os grupos sociais que reivindicam direitos". Cabe aqui a pergunta fundamental que tem sido feita pelos críticos da ACD, sobretudo Toolan (1997) - que elementos textuais, presentes no dado analisado, apontam para essa interpretação? Se existe, no dado investigado pelo autor de DELTA 3, a naturalização de discursos hegemônicos e a presença de ideologias que representam os grupos dominantes, quais elementos textuais indicam convincentemente essas relações assimétricas de poder e de jogos de interesse? Como afirma Toolan (1997, p. 88), o que é, de fato, necessário são 
análises textuais convincentes da naturalização de discursos hegemônicos nos dados, e não mera afirmação de que a naturalização existe afinal.

Já DELTA 4, embora tenha analisado um único excerto e tentado generalizar suas conclusões, apresenta uma análise linguístico-discursiva minuciosa e transdisciplinar do texto jornalístico de Nelson Ascher, partindo de teorias pós-coloniais e da ACD. Os autores de DELTA 4 dialogam satisfatoriamente com teorias sociais acerca da ocidentalização islâmica e das questôes do orientalismo. DELTA 4 conclui suas análises dizendo que:

\section{DELTA 4:}

Presenciamos, ao longo do percurso proposto, a construção de um posicionamento ocidentalista e a fabricação de uma ótica fundamentalista travestida por um discurso libertador e emancipador. Vimos que tal encadeamento de idéias articula diferentes discursos que, embora não sejam uniformes, trabalham com a noção de risco frente ao menos desenvolvido, fornecendo um caminho compartilhado para o discurso bélico no qual a eliminação do perigo é necessária para a democracia. Tal lógica engendra uma ideologia sintonizada com o credo ocidentalista dominante, e com uma face do projeto neoliberal que nele se insere, de que o mais moderno, o mais desenvolvido e o mais novo são melhores para todos e devem ser levados ao mundo pelos que se encontram em um estágio mais avançado e iluminado da humanidade. Argumentamos, a partir da perspectiva de outros profissionais da mídia, que a fabricação deste tipo de discurso moveu os neoconservadores americanos e o presidente George W. Bush a incitar seus oficiais a estar preparados para atacar imediatamente qualquer recanto obscuro do planeta, assim como parece ter movido o jornalista da Folha de São Paulo a propor a reeducação do Islã (MOITA LOPES; FABRÍCIO, 2005, p. 274-275).

Dos artigos analisados nessa seção, DELTA 4 revela-se mais sintonizado com os propósitos da ACD e seus métodos de análise, porque apresenta nos dados investigados as práticas sociais que pretende desvelar. Considero pertinente apresentar um exemplo de análise de DELTA 4 que demonstra os critérios analíticos adotados por seus autores:

\section{DELTA 4:}

Observemos, a seguir, o primeiro parágrafo:

$01 \mathrm{O}$ ano de 2002 foi um ano de terrorismo intensivo e violência mundo afora

02 cerca de 200 turistas mortos na explosão de uma discoteca em Bali e outras tantas 
03 vítimas, majoritariamente cristãs, linchadas na Nigéria; ataques no Paquistão a um

04 consulado americano, a engenheiros navais franceses, a organizações e templos

05 cristãos; alvos cristãos atacados nas Filipinas e uma sinagoga bombardeada na

06 Tunísia, vitimando turistas alemães; a destruição de um hotel e o lançamento de

07 mísseis terra-ar portáteis contra um jato comercial israelense no Quênia; vários

08 atentados contra a Índia; a tomada de reféns num teatro em Moscou por rebeldes

09 tchetchenos; o ataque a um petroleiro francês perto da costa do Iêmen. O maior

10 número de atentados, porém, ocorreu contra a população civil de Israel e, embora

$1190 \%$ deles tenham sido evitados, os bem-sucedidos resultaram em centenas de

12 mortos e milhares de feridos e mutilados.

O trecho acima é construido para explicitar quem são as "vítimas majoritariamente cristãs" (linha 03) de uma série de atentados perpetrados em várias partes do mundo e de outros contra a população civil de Israel. Percebe-se, contudo, que há uma generalização em relação ao que é descrito como cristão (uma categorização de natureza religiosa) para dar conta de populaçôes civis de paises, majoritariamente, ocidentais ("um consulado americano, linha 04; "engenheiros navais franceses", linha 04; "turistas alemãs, linha 06; "reféns de um teatro em Moscou", linha 08; "petroleiro francês", linha 09). Qual o objetivo de caracterizar cidadãos de paises especificos como um grupo religioso? O que levaria o autor a incluir todos esses grupos como cristãos ou como pertencentes ao mundo judaico-cristão? Além disso, outras escolhas lexicais situam os atores sociais, majoritariamente cristãos, no campo semântico da vitimização: "inchadas", "bombardeadas", "vitimadas", "ataque", "atentado", "tomada de reféns", "feridos" $e$ "mutilados", entre outros. Tal sistema de nomeação automaticamente sugere a existência de algozes e perpetradores. Quem são eles? (MOITA LOPES; FABRÍCIO, 2005, p. 262).

Os autores de DELTA 4 apresentam a análise dos dados de modo progressivo, como num crescendo, fazendo interconexões claras e lógicas entre os excertos analisados. É importante perceber que a todo instante os autores apontam nos dados as relações de poder frequentemente postas no texto, ligando-as aos fatos sociais em pauta. Ao dialogar com as teorias pós-colonias, 
com as questôes identitárias e a ACD, DELTA 4 traduz a transdisciplinaridade necessária em pesquisas de cunho crítico, como afirmou Hammersley (1997). Nesse sentido, DELTA 4 não só interpreta seus dados, movimento importante em análises críticas, como também mostra nos dados os elementos textuais que sinalizam as práticas sociais que os autores tencionam desvelar, caracterizandose, assim, como análise propriamente dita. Esse padrão analítico é recorrente em todas as análises de DELTA 4.

\section{Considerações finais}

Neste artigo, tentei mostrar em que momentos os trabalhos de alguns pesquisadores nacionais, orientados pela $\mathrm{ACD}$, refletiam algumas das críticas feitas a essa disciplina no contexto internacional. Embora apenas quatro artigos tenham sido analisados, pude perceber que alguns dos questionamentos à lógica de investigação da ACD, apresentados por Widdowson, Hammersley, Stubbs e Toolan, ecoaram nas análises do corpus escolhido para discussão. Esse aspecto leva-nos a revisitar os métodos de análise de cada pesquisa e de suas abordagens em particular. Ademais, neste artigo ficou evidente que as análises feitas resultam apenas do corpus escolhido para estudo, não cabendo, portanto, generalizações acerca das discussões apresentadas. O que de fato pôde ser depreendido dessas discussões é a necessidade de observância dos critérios analíticos usados em nossas pesquisas, cuja orientação seja uma perspectiva crítica, tal qual posta pela ACD.

Cabe agora meu posicionamento como analista crítico do discurso em relação às discussões aventadas neste trabalho. Uma das potencialidades da ACD está nas análises linguísticas realizadas para desvelar relações opacas de poder hegemonicamente constituídas nos discursos. Dessas análises, é possível depreender como a linguagem representa, ou instancia, um momento discursivo específico, sendo igualmente um mecanismo poderoso de prática social. Tendo em mente essas ponderações, penso que as colocações de Stubbs (1997) e Toolan (1997) acerca dos processos de análise linguística típicos da ACD contribuem para uma sistematização dessas análises, por meio de definiçōes claras de quais elementos linguístico-discursivos representam os objetivos ideológicos que os produtores do discurso tencionam engendrar. Esses elementos, muito claros, por exemplo, nas análises de DELTA 3, contribuem para a identificação da materialização do discurso em instâncias textuais, contribuindo, de igual modo, para o entendimento da linguagem como mecanismo de prática social. 
Em vista desses apontamentos, problematizo as colocações de Widdowson (2003) a respeito da dicotomia análise-interpretação. Retomando suas ponderaçôes, esse linguista aplicado afirmou que os analistas críticos do discurso apenas interpretam seus dados, não levando em consideração processos de análise mais específicos e detalhados. Ora, no âmbito das Ciências Humanas, é possível fazer análise sem interpretação? Se, para Widdowson, análise é um fenômeno sistemático, que aponta nos dados elementos recorrentes de uma determinada escolha léxico-gramatical, a ocorrência, por exemplo, de um único elemento não deveria ser também levada em consideração? A ocorrência frequente, tal qual a ocorrência particularizada de um único elemento linguístico, aponta para posicionamentos de seus produtores que merecem, sem dúvida, uma análise interpretativa sistemática. Há momentos que para os analistas críticos do discurso um único evento linguístico traduz relações camufladas de poder que talvez não estivessem presentes em eventos linguísticos recorrentes.

Essas ponderaçóes nos levam à questão da representatividade dos dados, conforme posta por Stubbs (1997), e às possibilidades analíticas que essa questão proporciona aos analistas críticos do discurso. Ao questionar a validade das análises da maioria das pesquisas em $\mathrm{ACD}$, porque não contemplam dados representativos para respaldar as generalizaçôes aventadas na maioria dessas pesquisas, Stubbs afirma que os analistas críticos do discurso analisam fragmentos de textos e generalizam suas conclusões a partir dessas análises. Esse fato ficou claro, por exemplo, nas perquiriçōes de DELTA 4. Embora eu concorde com Stubbs sobre essa questão, isso, entretanto, não significa que fragmentos textuais não possam ser analisados, tendo em vista a identificação e interpretação de elementos linguísticos específicos. O que, no entanto, não se aplica nesse procedimento metodológico são generalizaçôes feitas a partir das análises de meros fragmentos. Esse problema pôde ser amplamente percebido nas discussões de DELTA 2, uma vez que sua autora teceu conclusões generalizadas sobre a prática pedagógica de um professor, tendo como base apenas três eventos interacionais de sua sala de aula. Análises desse teor conduzem, na maioria das vezes, a conclusões precipitadas e, especialmente, à disseminação de juízos de valor. Nesse sentido, a crítica, como defendida pela ACD, perde seu valor porque resvala no campo das opiniões próprias e do senso comum.

Por fim, esse fato nos leva às colocações de Hammersley que, a meu ver, são o grande desafio dos analistas críticos do discurso. O entendimento do 
conceito sociológico de criticismo, historicamente constituído, permeia boa parte das preocupaçôes teórico-metodológicas da $\mathrm{ACD}$, embora o conceito tenha recebido um tratamento teórico às vezes superficial no cerne dessa disciplina, como visto nas análises feitas em DELTA 2. Publicações como a de Chouliaraki e Fairclough (1999), no entanto, buscaram preencher essa lacuna, ao tratarem o termo "crítico" a partir de teorias sociológicas que discutem amplamente esse conceito, situando-o na constituição histórica de seu significado. Mesmo assim, há ainda um longo caminho de discussões e apontamentos a ser percorrido nesse sentido, até que os analistas críticos do discurso consigam atingir análises realmente transdisciplinares, tais quais as proposiçôes apresentadas por Fairclough e seus colegas. Do corpus investigado neste trabalho, somente DELTA 4 se aproximou de uma discussão sociológica nessa direção, ao dar ênfase à visão hegemônica dos discursos de ocidentalização do Islã, orientada por teorias pós-coloniais.

Para finalizar minhas colocaçôes, é necessário responder à questão apresentada no título deste artigo - a ACD é um modismo, como afirmou Widdowson (2003), uma teoria, ou um método? Apesar de Chouliaraki e Fairclough (1999) terem afirmado que a ACD é teoria e método, questiono se as várias formas de análise, orientadas pelos fenômenos sociais de interesse dos analistas críticos do discurso, podem seguir um único padrão investigativo. Penso que as escolhas metodológicas dependerão dos fenômenos em pauta, cujos objetivos serão variados e dependentes das problemáticas apresentadas. No que se refere à teoria, a ACD tem estabelecido uma agenda que procura desvelar relações de poder ofuscadas nos discursos que investiga. Nesse aspecto, a ACD é a teoria que orienta essa investigação, tendo contribuído substancialmente para o entendimento dessas relações de hegemonia e poder em vários tipos de textos, especialmente nos media. Quanto ao modismo, considero a ACD uma teoria que veio expandir algumas teorias, no campo da $\mathrm{AD}$, que não extrapolavam a superfície do discurso, inaugurando, por assim dizer, no contexto anglo-saxônico, aportes teóricos que procuram dar conta das intrincadas e complexas relações entre discurso e poder. Sua importância para o entendimento da linguagem como prática social é inquestionável, mas os modos de abordagem que os analistas críticos do discurso adotam precisam receber atenção cuidadosa, no que tange aos métodos usados, às análises feitas e às conclusões sobre o fenômeno social investigado. 


\section{Referências}

BARDIN, L. Análise de conteúdo. 3 ed. Lisboa: Edições 70, 2004.

BELL, A. The language of news media. Oxford: Blackwell, 1991.

BRAVO, G. M. Burguesia. In: BOBBIO, N.; MATTEUCCI, N.; PASQUINO, G. (Ed.). Dicionário de Política. V. 1. 12. ed. Brasília: LGE Editora e Editora da UnB, 2004. p. 119-124.

CHOULIARAKI, L.; FAIRCLOUGH, N. Discourse in late modernity: rethinking critical discourse analysis. Edinburgh: Edinburgh University Press, 1999.

DURANTI, A. Linguistic anthropology. Cambridge: Cambridge University Press, 1997.

DURANTI, A.; GOODWIN, C. (Ed.). Rethinking context: language as an interactive phenomenon. Cambridge: Cambridge University Press, 1992.

FAIRCLOUGH, N. Analysing discourse: textual analysis for social research. London e New York: Routledge, 2003.

Discourse and social change. Cambridge: Polity Press, 1992.

Language and power. London: Longman, 1989.

. The discourse of new labour: critical discourse analysis. In:

WETHERELL, M.; TAYLOR, S.; YATES, S. J. (Ed.). Discourse as data. London, Thousand Oaks and New Delhi: Sage and The Open University, 2001. p. 229-266.

FOLEY, W. A. Anthropological linguistics: an introduction. USA/UK: Blackwell Publishers, 1997.

FOWLER, R. et alli. Language and control. London: Routledge, 1979.

HALLIDAY, M. A. K. An introduction to functional grammar. 2. ed. London e New York: Edward Arnold, 1994.

Arnold, 1985.

An introduction to functional grammar. London e New York: Edward Language as social semiotic. London e New York: Arnold, 1978.

HALLIDAY, M. A. K.; MATTHIESSEN, C. M. I. M. An introduction to functional grammar. 3. ed. UK: Arnold, 2004.

HAMMERSLY, M. On the foundations of critical discourse analysis. Language \& Communication, v. 17, n. 3, p. 237-248, 1997.

HODGE, R.; KRESS, G. Social Semiotics. Cambridge: Polity Press, 1988.

KRESS, G. Critical discourse analysis. Annual Review of Applied Linguistics, v. 11 , n. 84, p. 84-99, 1990.

Linguistic processes in socio-cultural practice. Geelong, Vic.: Deakin

University Press, 1985. 
LEAL, M. C. D. O discurso jornalístico sobre privatizações e protestos nas ruas. D.E.L.T.A. Especial, n. 21, p. 73-92, 2005.

MAGALHÃES, I. Introdução: a análise de discurso crítica. D.E.L.T.A., v. 21, n. especial, p. 1-9, 2005.

MARTIN, J. R. Close reading: functional linguistics as a tool for critical discourse analysis. In: UNSWORTH, L. (Ed.). Researching language in schools and communities. London e Washington, 2000. p. 275-302.

MARTINS, A. R. N. Grupos excluídos no discurso da média: uma análise de discurso crítica. D.E.L.T.A. Especial, n. 21, p. 129-147, 2005.

MOITA LOPES, L. P.; FABRÍCIO, B. F. Discurso como arma de guerra: um posicionamento ocidentalista na construção da alteridade. D.E.L.T.A. Especial, n. 21, p. 239-283, 2005.

RODRIGUES JÚNIOR, A. S. Linguística de corpus e os estudos da tradução: o estado-da-arte, Polissema, v. 5, n.5, p.7-21, 2005.

RYAN, A.; WRAY, A. (Ed.). Evolving models of language. Clevedon: Multilingual Matters, 1997.

SEIDLHOFER, B. (Ed.). Controversies in Appliede Linguistics. Oxford: Oxford University Press, 2003.

SILVA, D. E. G. Motivações cognitivas e interacionais em competição: a força das palavras em contexto. D.E.L.T.A. Especial, n. 21, p. 93-103, 2005.

SIMPSON, P. Language, ideology and point of view. London e New York: Routledge, 1993.

STOPPINO, M. Ideologia. In: BOBBIO, N.; MATTEUCCI, N.; PASQUINO, G. (Ed.). Dicionário de Política. Vol. 1. 12. ed. Brasília: LGE Editora e Editora da UnB, 2004. p. 585-597.

STUBBS, M. Text and corpus analysis; computer-assisted study of language and culture. Oxford: Blackwell, 1996.

Words and phrases: corpus studies of lexical semantics. Oxford: Blackwell, 2002.

TOOLAN, M. What is critical discourse analysis and why are people saying such terrible things about it? Language and Literature, v. 6, n. 2, p. 83-103, 1997.

van DIJK, T. A. Communicating racism: ethnic prejudice in thought ant talk. Newbury Park, CA: Sage, 1987. . Elite discourse and racism. Newbury Park, CA: Sage, 1993.

Ideology: a multdisciplinary approach. London, Thousand Oaks, New

Delhi: Sage, 1998. 
van DIJK, T. A. News as discourse. Hillsdale, NJ: Erlbaum, 1988.

Prejudice in discourse. Amsterdam: Benjamins, 1984.

Racism and the press. London: Routledge e Kegan Paul, 1991.

van LEEUWEN, T. Genre and field in critical discourse analysis. Discourse \& Society, v. 4, n. 2, p. 249-283, 1993.

. The representation of social actors. In: HASAN, R.; WILLIAMS, G. (Ed.). Literacy in society. London: Longman, 1996. p. 32-70.

WIDDOWSON, H. Discourse analysis: a critical view. In: SEIDLHOFER, B. (Ed.). Controversies in applied linguistics. Oxford: Oxford University Press, 2003. p. 132-145.

Discourse analysis: a critical view. Language and Literature, v. 4, n. 3, p. 136-151, 1995.

Reply to Fairclough: discourse and interpretation: conjectures and refutations. Language and Literature, v. 5, n. 1, p. 57-69, 1996.

WODAK, R. Discourse analysis: problems, findings, perspectives. Text, v. 10, n. 1/2, p. 125-132, 1990.

WODAK, R.; REISIGL, M. Discourse and racism. In: SCHIFFRIN, D.; TANNEN, D.; HAMILTON, H. E. (Ed.). The handbook of discourse analysis. USA/UK: Blackwell Publishers, 2001. p. 372-397.

Recebido em abril de 2008. Aprovado em junho de 2008. 